\title{
REVIEW ARTICLE \\ Geoinformation Systems in the Development of Solar Energy in Turkmenistan
}

\author{
A.M.Penjiyev* \\ Turkmen State Institute of Architecture and Civil Engineering, 744032, Turkmenistan
}

Received: 22 December 2021; Accepted: 20 January 2022; Published Online: 25 January 2022

\begin{abstract}
The article considers the scientifically substantiated, systematized solar energy resource potentials of Turkmenistan. Geoinformation technological maps based on solar energy resource potentials for use in Turkmenistan have been developed, compiled. The obtained technical, economic potentials and environmental indicators from the use of power plants based on them have been developed. Solar geoinformation technological maps for the placement of water-lifting plants and solar thermal cells make it possible to increase energy efficiency and environmental safety. The expected environmental and economic effect of the use of solar-energy technological installations in the conditions of the Karakum desert zone is from: reduction of various harmful substances into the environment when selling at a price of 6 US dollars to $\mathrm{CO}_{2}$ carbon fund - 425437.3 tons per year, financial profit will be $\$ 2.5$ million; fossil fuel savings 82.160 thousand tons of fuel equivalent per year or electricity generation of $663.4 \mathrm{GWh}$ per year.
\end{abstract}

Keywords: Geographic information systems, Maps, Solar energy, Installations, Technologies, Energy supply, Energy efficiency, Karakum desert, Turkmenistan

\section{Introduction}

The urgency of the problem. Turkmenistan actively implements a policy of positive neutrality in the system of international relations and supports the solution of world energy, economic and environmental problems.

At the inauguration of Gurbanguly Berdimuhamedov for the post of President of Turkmenistan (2017), it was emphasized that the country will provide great support for the efficient use of renewable energy sources (RES). A fundamentally new integrated approach is environmental policy, the issues of the UN Convention on Climate Change, to combat desertification and the development of deserts ${ }^{[1-3,5]}$.

To achieve the main goal of the energy strategy of Turkmenistan, it is necessary to solve a number of interrelated tasks, including: ensuring energy security and interaction of the fuel and energy sector with the country's economy in the interests of the population; increasing energy efficiency by optimizing the capacity of power generating structures, introducing innovative energy

*Corresponding Author:

A.M.Penjiyev,

Turkmen State Institute of Architecture and Civil Engineering, 744032, Turkmenistan;

Email: ampenjiev@rambler.ru

DOI: https://doi.org/10.54963/neea.v1i1.11

Copyright (C) 2022 by the author(s). Published by UK Scientific Publishing Limited. This is an open access article under the Creative Commons Attribution (CC BY) license (https://creativecommons.org/licenses/by/4.0/). 
saving technologies; economic assessment, assistance in the development of the country's resource base; support of the scientific, technical and organizational potential of the fuel and energy complex; increasing the economic efficiency of innovative transformations in the spheres of production, transmission of energy and the use of the formation of mechanisms of state regulation, the functioning of the energy sector ${ }^{[3]}$.

The territory of Turkmenistan is $80 \%$ occupied by the Karakum Desert, and a significant number of people live in the zone of decentralized energy supply, therefore, the development of technology and the use of renewable energy resources is an urgent problem. RES resources in terms of volume can cover a significant part of the consumption of fuel and energy resources and solve urgent energy, economic, environmental and social problems in Turkmenistan ${ }^{[3-5]}$.

A lot of work has been done in Turkmenistan on the use of renewable energy sources, in particular, in solar energy, significant scientific results have been achieved. At the same time, there is a lack of foundations for a scientific generalizing, systematic analysis of energy potentials. The regions of Turkmenistan that have significant renewable energy resources for the use of energy efficient technologies and installations based on renewable energy sources have not been identified, recommendations have not been formulated for the implementation of developments, development and development of renewable energy energy potentials, taking into account innovative techniques. Geoinformation technological maps and nomograms were not compiled for a feasibility study (FS) ${ }^{[7,8]}$.

Geographic information system or geographic information systems (GIS) is a new direction, which is used as a tool for technological solutions that allows you to search for additional information, analyze in this case a digital technological map of the area, taking into account scientific and engineering knowledge, technical, energy, economic, environmental potentials for use RES ${ }^{[8]}$.

The results of scientific research will fill this gap and will contribute to the large-scale development of renewable energy, saving energy resources, improving the socio-economic and living conditions of pastures, reducing the anthropogenic load on the environment and climate change. On the basis of a literature review, scientific research on the use of renewable energy sources in Turkmenistan, the goals and objectives of research work have been determined.

\section{Purpose of work}

Scientifically substantiate, systematize, calculate and study solar energy potentials for the development, creation, implementation and use of energy technologies based on renewable energy sources for sustainable development of Turkmenistan.

\section{Research methodology}

Based on a systematic approach to the object of research as an integral complex of theoretical, practical and experimental works using energy technologies based on renewable energy sources for sustainable development of Turkmenistan. The subject of research is the energy efficiency of complex renewable energy technologies for the use of water supply and the development of the Karakum desert. The methodological base of the research was formed by the developed mathematical models, theoretical obtained empirical formulas, created geoinformation technological maps, proposed developments, experimentally implemented power plants based on renewable energy sources in various industries of Turkmenistan.

\section{Geoinformation Technologies in the Deve- lopment of Renewable Energy}

The development of renewable energy (RE) currently requires solving not only technological problems, the adoption of legislative acts, the provision of state financial support for projects, but also substantiation of issues related to the analysis of energy resource potentials of various types of renewable energy sources (RES).

Renewable energy sources include energy sources of solar origin: solar radiation, wind, hydraulic energy of rivers, biomass, seas and oceans), non-solar energy (geothermal energy, energy of tides), various waste and low-potential heat sources.

The types of renewable energy sources are wide and heterogeneous in the presented scientific article, energy resource potentials (technical, economic, environmental) compiled by geoinformation maps of solar energy on the territory of Turkmenistan are considered ${ }^{[3-8]}$.

Vast geographic datasets have been accumulated that provide the actual basis for RES for the use of renewable energy technologies in various forms. Moreover, in addition to the problem of verifying these data, analyzing the adequacy of methods for obtaining them, there are difficulties in their visual display in a form convenient for analysis. An important task is to accumulate them in the form of databases, as well as to map the potential of solar energy for use in various regions of the country.

In addition to the scientific and methodological significance, such studies are of great practical relevance, 
since databases of geographic information systems (GIS) should become an important tool for analyzing the energy efficiency of the practical use of solar energy in various regions of Turkmenistan, in particular the Karakum desert and drawing up a feasibility study in the preparation of design estimate documentation and management decisions of use, taking into account technological and economic indicators ${ }^{[6-8]}$.

\section{Scientific Research of the Development of Creating a GIS Technological Map}

In the course of scientific theoretical and experimental research, solar energy technologies and installations have been studied. The bases of the use of solar energy potentials on the territory of Turkmenistan have been scientifically substantiated and theoretically systematized. A geoinformation solar energy map has been developed, see Figure 1.

On the basis of a GIS map, the energy characteristics of a solar greenhouse, photovoltaic modules under uneven illumination, solar installations with axisymmetric concentrators have been investigated, a geoinformation technological map has been developed for placing solar water-lifting installations in the Karakum desert.

The theoretical, experimental calculated results are systematized according to a formalized method, resource potentials and the volume of reduction of anthropogenic loads on the environment from the use of solar power plants when converted into thermal and electrical energy are determined. The calculations took into account the natural and climatic conditions: the astronomical duration of the sunshine during the month; average annual and monthly operating temperature of the solar installation and the environment; the fraction of scattered radiation, surface albedo, angular parameters of the arrival of solar energy on an inclined and normally oriented surface during a month; hour angle of movement of solar declination and inclination of the surface to the horizon; specific energy parameters of a solar installation. Until now, such calculations with the assessment of technical, economic, potentials and environmental indicators have not been carried out in Turkmenistan. The results are shown in Table $1^{[8]}$

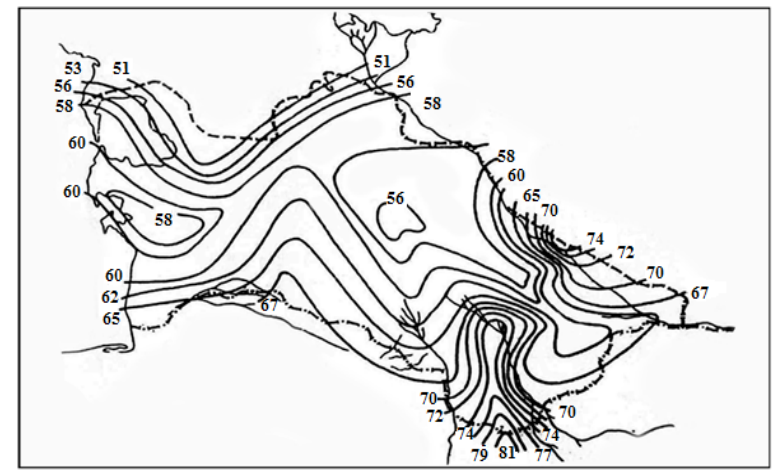

Figure 1. Geographic information map of the solar-energy balance in the territory of Turkmenistan ( $\mathrm{Wt} \mathrm{h} / \mathrm{cm}^{2}$ year)

The distribution of the gross and technical potentials of solar energy during conversion into thermal energy and electricity in the Central Karakum by months $\left(\mathrm{kWh} / \mathrm{m}^{2}\right.$ per month) has been calculated; the histogram is shown in Figure 2 .

Table 1. The energy resource potentials of solar energy from conversion into thermal and electric energy from $1 \mathrm{sq}$. meters by regions of Turkmenistan

\begin{tabular}{|c|c|c|c|c|c|c|c|c|}
\hline \multirow{2}{*}{$\begin{array}{c}\text { Resources } \\
\text { gross, } \\
\left(\mathrm{kWh} / \mathrm{m}^{2} \text { year }\right)\end{array}$} & \multicolumn{2}{|c|}{ Potentials } & \multicolumn{6}{|c|}{ Anthropogenic load of harmful substances, $\left(\mathrm{kg} / \mathrm{m}^{2}\right.$ year) } \\
\hline & $\begin{array}{c}\text { Technical, (kWh / } \\
\text { m }^{2} \text { year) }\end{array}$ & $\begin{array}{c}\text { Fuel economy (kg c.f. } \\
\mathrm{m}^{2} / \text { year) }\end{array}$ & $\mathrm{SO}_{2}$ & $\mathbf{N O}_{\mathrm{x}}$ & CO & $\mathbf{C H}_{4}$ & $\mathrm{CO}_{2}$ & Solids \\
\hline \multicolumn{9}{|c|}{ Northern region } \\
\hline \multirow{3}{*}{1757,4} & $1227,59^{*}$ & 490,90 & 10,20 & 5,49 & 0,71 & 1,50 & 784,96 & 1,07 \\
\hline & $244,84^{* *}$ & 97,94 & 2,035 & 1,09 & 0,14 & 0,31 & 156,62 & 0,21 \\
\hline & \multicolumn{8}{|c|}{ Southeast region } \\
\hline \multirow{2}{*}{1895,9} & $1296,78^{*}$ & 518,74 & 10,78 & 5,80 & 0,75 & 1,59 & 829,49 & 1,13 \\
\hline & $248,55^{* *}$ & 99,44 & 2,07 & 1,11 & 0,14 & 0,30 & 158,98 & 0,22 \\
\hline \multicolumn{9}{|c|}{ Region Central Karakum } \\
\hline \multirow{2}{*}{1844,6} & $1256,44^{*}$ & 502,61 & 10,44 & 5,62 & 0,72 & 1,54 & 803,68 & 1,09 \\
\hline & $242,44^{* *}$ & 96,98 & 2,01 & 1,08 & 0,14 & 0,31 & 155,08 & 0,21 \\
\hline \multicolumn{9}{|c|}{ South region } \\
\hline \multirow{2}{*}{1725,6} & $1234,46^{*}$ & 493,81 & 10,26 & 5,52 & 0,71 & 1,51 & 789,62 & 1,10 \\
\hline & $225,29^{* *}$ & 90,14 & 1,87 & 1,01 & 0,13 & 0,28 & 144,11 & 0,20 \\
\hline \multicolumn{9}{|c|}{ West region } \\
\hline \multirow{2}{*}{1685,4} & $1177,12^{*}$ & 470,88 & 9,78 & 5,26 & 0,68 & 1,44 & 752,9 & 1,02 \\
\hline & $222,60^{* *}$ & 89,06 & 1,85 & 0,99 & 0,13 & 0,27 & 142,4 & 0,20 \\
\hline
\end{tabular}

Note: in the line * conversion to heat energy; ${ }^{* *}$ - electricity. 


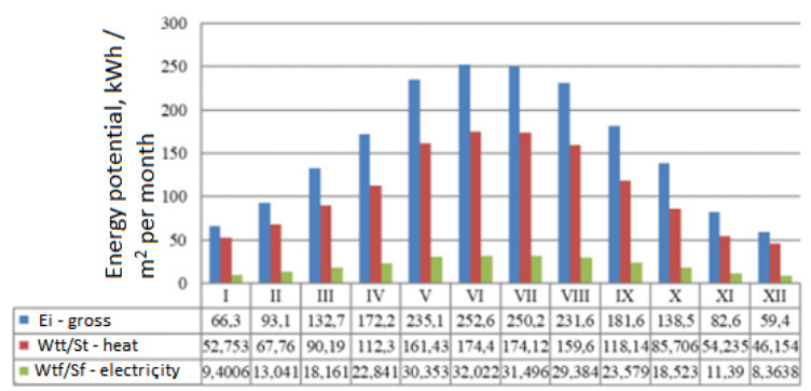

Figure 2. Distribution of gross and technical potentials of solar energy from conversion to thermal energy and electricity in the Central Karakum Desert by months per 1 square meter

Development, creation and research of the energy characteristics of a solar greenhouse for growing tropical and subtropical crops. Among the known works, there is not a single development that could be directly used to calculate the thermal characteristics of trench type solar greenhouses. Physical characteristics are considered, a mathematical model of heat engineering characteristics in a classical form for creating a microclimate in a solar greenhouse is compiled.

The calculation of the heat balance of a trench-type solar greenhouse is presented as a system of heat balance equations for a solar airspace structure, for a time interval $\mathrm{d} \tau$, taking into account additional heating in $\mathrm{kWh}$, which can be written as:

$\mathrm{dQob}+\mathrm{dQ} \mathrm{p}+\mathrm{dQw}+\mathrm{dQt}+\mathrm{dQst}+\mathrm{dQp}+\mathrm{dQa}+\mathrm{dQp}=0$

where dQob is the heat dissipation of the heating system; dQ p is the heat flux of solar radiation entering the solar structure; dQw.t - the amount of heat given to the environment as a result of air exchange and heat transfer through the fences; dQst $=\mathrm{dQ} * \mathrm{st}+\mathrm{dQost}$ - heat flow into the wall; dQp $=\mathrm{dQp} *+\mathrm{dQpo}-$ heat flow into the soil, dQ * p (st), dQp (st) o - heat flux to the illuminated and unlit parts of the wall and soil; dQ is the heat flux accumulated in the air; dQp - heat flux on the vegetation cover (provided that the greenhouse is full of plants). Unit of measurement $\mathrm{kWh}$ per area. The heat balance equation for the soil surface and the wall is written in a similar way, as the heat balance equation for the soil, the wall of its illuminated and unlit parts.

As a result of mathematical transformations of Equation (1), the temperature regime of the solar greenhouse in the temporary total heat flow has the form ${ }^{[6]}$ :

$\theta_{B}=\int_{o}^{\tau} I(\delta) \exp [-h(\tau-\delta)] d \delta-\sum_{i=1}^{4} \frac{B i(\tau)}{R_{i}}$,

Studies of a complex and simplified mathematical model of the thermal engineering parameters of a trench solar greenhouse have been carried out. The obtained calculation results showed that a complex and simplified mathematical model adequately reproduces the results of the experiment, with an accuracy: a complex model $12.35 \%$; simplified - $23.11 \%$. Similarly, a mathematical model of heat and mass transfer and determination of the temperature of the leaf surface of a plant in a solar greenhouse was compiled and considered. The physical model of thermal engineering processes occurring in a trench type solar greenhouse, taken in the calculations, is shown in detail in the monograph.

On the basis of scientifically substantiated results and mathematical modeling of thermal engineering processes, nomograms were created, see Figure 3, empirical expressions 3-8 and geographic information technological maps of the optimal zoning of solar greenhouses in the country, see Figures 4 and 5.

The nomogram for determining the air temperatures in the greenhouse depending on the amount of incoming solar radiation in the Ahal regions of Turkmenistan are shown in Figure 3, similar nomograms are compiled for the Dashoguz, Lebap and Balkan regions and are given in monographs ${ }^{[6]}$.

Taking into account the heat engineering parameters, empirical formulas were obtained, expanded in Fourier series for the outside air temperature Tn, direct solar radiation $\mathrm{I}$, soil and trench walls, have the form:

$$
\begin{gathered}
T_{\text {н }}=12,6+10 \cos (0,26 t+0,18)+3,27 \cos (0,52 t-0,44) \\
+1,39 \cos (0,78 t+0,23) \\
I=129,9+217,9 \cos (0,26 t+0,13)+120,4 \cos (0,52 t-0,26) \\
+26,9 \cos (0,78 t-0,3) .
\end{gathered}
$$

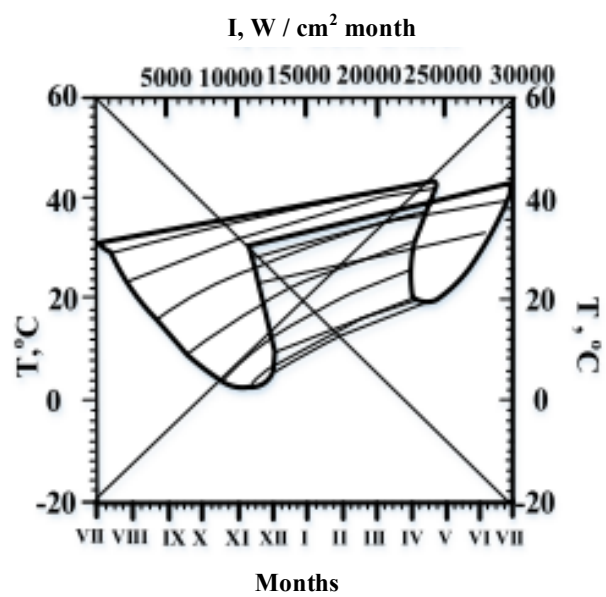

Figure 3. Nomogram for determining the air temperature depending on the incident solar radiation for the Akhal velayat (region)

Substituting Tn and I into expressions (3-4), we obtain dependencies describing the temperature regime of air and soil: 


$$
\begin{aligned}
\mathrm{T}_{B}=16,2+8,3 \cos (0,26 t+0,28)+2,8 \\
\cos (0,52 t-0,08)+0,97 \cos (0,78 t-1,42) ; \\
\left.\mathrm{T}_{n}\right|_{x=0}=21,1+8,59 \cos 0,26 t+3,19 \cos 0,52 t \\
+0,72 \cos 0,78 t ; \\
\left.\mathrm{T}_{n}\right|_{x=0,1}=19,58+3,78 \cos 0,26 t+1,01 \cos 0,52 t \\
+0,17 \cos 0,78 t .
\end{aligned}
$$

Equations for the walls of the solar greenhouse trench are described similarly.

The compiled geoinformation map of the average isotherm of the outside air and the trench type solar greenhouse in the month of January (marked in red), similarly the map for the month of July is shown in Figure $4 \mathrm{a}, \mathrm{b}$. The results of implementation and commissioning are confirmed by acts, research protocols, certificates. Study of the energy parameters of the solar module. To create a solar photovoltaic station, experimental studies of the volt-watt (VVC) and volt-ampere characteristics (VAC) of modules of various foreign companies (Japan, Russia, Iran) have been carried out.

Research of photomodules was carried out in different climatic conditions and seasons during the day, with a change in the angle of inclination, orientation with tracking and without tracking, while studying the energy characteristics of: solar radiation; optimal current, shortcircuit current; optimal voltage and open circuit voltage; optimal power and efficiency.

Development of a geographic information map for the placement of solar photovoltaic water-lifting units (SHEP) in the Karakum desert. All livestock settlements in the Karakum Desert have wells far from power lines, their water reserves are estimated at $80 \mathrm{~km}^{3}$, the cost of $1 \mathrm{~km}$ of power lines is 18 - 25 thousand US dollars, the construction of power lines is not economically profitable. On the territory of Turkmenistan there are more than 5,000 wells with a depth of $5-250 \mathrm{~m}$. The load capacity of the pump has been determined depending on the pressure at various capacities. On the basis of the terrain, depth, flow rate of wells, a geoinformation technological cartogram of the location of the NEFU according to the power of the generated energy was compiled and introduced, depending on the depth of the wells of the desert pasture territories of the Karakum. On the basis of the above scientific research, the SFED was developed, created and put into operation in the Garygul settlement in the Central Karakum at the research base of the National Institute of Deserts, Flora and Fauna (NIPRiZhM) $100 \mathrm{~km}$ from Ashgabat.

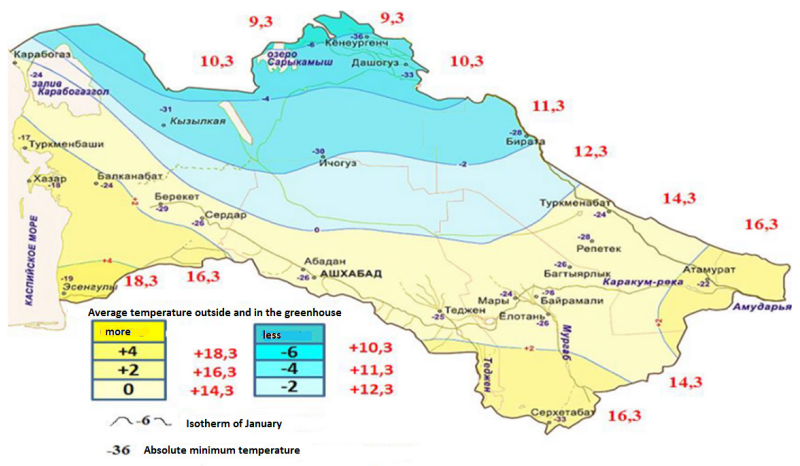

a)

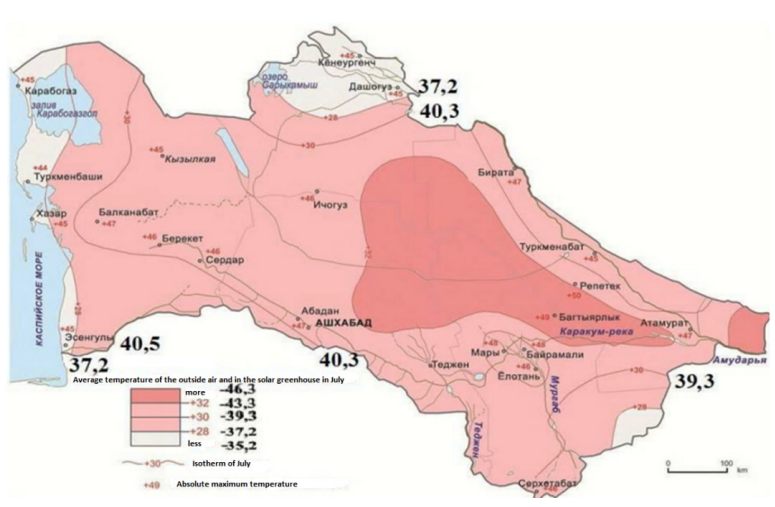

b)

Figure 4. Map of the average isotherm of the outside air and trench type solar greenhouse in January (a) and July (b) by regions of Turkmenistan

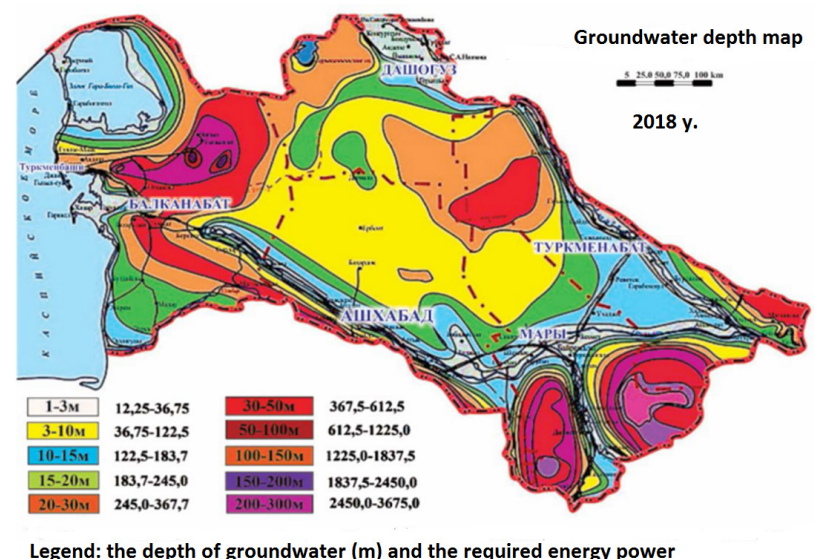

Figure 5. Geo-information technological map, placement of SFEU according to the power of generated energy, depending on the depth of wells in the pasture areas of

Turkmenistan

The total power of the installation is: $450 \mathrm{~W}$, with a pressure of $30 \mathrm{~m}$. The developed scheme of the SFVU and the automated control system are given in my scientific articles and monographs.

Implementation act, certificate of scientific and 
technical use of the results of work, test report, photographs in the thesis attachment.

The developed installation can be used for water supply and other facilities ${ }^{[3-8]}$.

\section{The Results of Scientific Research}

On the basis of scientifically substantiated systematized energy resources, potentials and implemented energy technologies based on RES for Turkmenistan, the following results were obtained:

\section{Solar energy}

Gross resources in $\mathrm{kWh} /\left(\mathrm{m}^{2}\right.$ year $)$ in the regions are equal: North - 1757.4; South-east - 1895.9; Central Karakum - 1844.6; South -1725.0; West -1685.4.

Technical potentials of conversion into heat energy and electrical energy in $\mathrm{kWh} /\left(\mathrm{m}^{2}\right.$ year $)$ in the regions, respectively: North - 1227.587 and 244.84; South-east - 1296.78 and 248.55; Central Karakum - 1256.44 and 242.44; Southern - 1234.46 and 225.29; West -1177.12 and 222.6.

Economic potentials from conversion to thermal and electrical energy are in $\mathrm{kg}$ of fuel equivalent per year: North - 490.9 and 97.9; Southeast - 518.7 and 99.44; Central Karakum - 502.6 and 96.98; South - 493.8 and 90.14; Western - 470.9 and 89.1.

Environmental indicators: the reduction of emissions of various harmful substances into the environment when using a solar photovoltaic station will be in the Central Karakum with an annual electricity generation from 1 $\mathrm{m}^{2}-242.44 \mathrm{kWh} / \mathrm{year}$, fuel economy $-96.98 \mathrm{~kg}$ of fuel equivalent / year, emission reduction will be, $\mathrm{kg} /$ year: sulfur dioxide $\mathrm{SO}_{2}-2.01$; nitrogen oxide $\mathrm{NOx}-1.08$; carbon monoxide $\mathrm{CO}-0.1401$; methane $\mathrm{CH}_{4} 0.296$; carbon dioxide $\mathrm{CO}_{2}-155.08$; solids - 0.211175 ; when converting to thermal energy from $1 \mathrm{~m}^{2}$ - annual production is $1256.44 \mathrm{kWh} /$ year, fuel consumption saving $-502.60 \mathrm{~kg}$ of fuel equivalent / year, emission reduction will be, $\mathrm{kg} /$ year: $\mathrm{SO}_{2}-10.44 ; \mathrm{NOx} 5.624 ; \mathrm{CO} 0.726 ; \mathrm{CH}_{4} 1.53 ; \mathrm{CO}_{2}$ 803.68; solids -1.094 .

\section{Conclusions}

Based on the analysis of the climatic characteristics of Turkmenistan, water resources, groundwater and the flow rate of the wells of the desert, a geoinformation technological map of the location of a solar photovoltaic water-lifting unit according to the power of the generated energy, depending on the depth of the wells in the pasture territories of Turkmenistan, was compiled. The use of cartographic material made it possible to calculate energy resources, reduce greenhouse gas emissions and reduce the consumption of fossil fuels for the development of 40 million hectares of pasture areas of the country.

The created and put into operation a solar photovoltaic water-lifting unit (SHPH) in the Central Karakum Desert on the experimental base of the National Institute of Deserts, Flora and Wildlife saves 12.0 tons of fossil fuel per year, makes a profit of 3830 US dollars while reducing $\mathrm{CO}_{2}$ emissions by 38,4 tons. Taking into account the priorities and prospects for the use of energy technologies based on RES in Turkmenistan under the Clean Development Mechanism (CDM) and the possibility of reducing greenhouse gas emissions in the fuel and energy complex, the areas for the development of solar energy and indicators of its energy efficiency have been identified. With the creation of a plant in Turkmenistan for the production of SFEU with an annual capacity of $20 \mathrm{MW}$ and an annual output of USD 14 million, the expected economic effect from the introduction of the plant's products will amount to USD 12 million per year, fossil fuel savings - $3554.4 \mathrm{t}$ u.t. in year. With an annual intake of solar radiation of at least $1200 \mathrm{kWh} / \mathrm{m}^{2}$ and the efficient use of this energy, it will be possible to provide up to $25 \%$ of heat consumption in heating systems, up to $50 \%$ in hot water supply systems and up to $75 \%$ in air conditioning systems, reduce the consumption of fossil fuel and to ensure the saving of fuel and energy resources of 2364 thousand tons of fuel equivalent. or $52.6 \%$, including in rural areas 1110.6 thousand tce. tons or $61.5 \%$.

\section{References}

[1] Berdymukhamedov, G.M., 2010. State Regulation of Socio-Economic Development of Turkmenistan vol. I / G.M. Berdimuhamedov -- Ashgabat: Turkmen State Publishing Service. pp. 498.

[2] Berdymukhamedov, G.M., 2018. Turkmenistan on the way to achieving the Sustainable Development Goals / G.M. Berdimuhamedov - Ashgabat: Turkmen State Publishing Service. pp. 468.

[3] Strebkov, D.S., Pendzhiev, A.M., Mamedsakhatov, B.D., 2012. Development of solar energy in Turkmenistan. - Moscow: GNU VIESH. pp. 498.

[4] Pendzhiev, A.M., 2012. Climate change and the possibility of reducing anthropogenic pressures. - Germany: LAP LAMBERT Academic Publishing. pp. 164.

[5] Pendzhiev, A.M., 2014. Ecological problems of the development of deserts. - Germany: LAP LAMBERT Academic Publishing. pp. 226.

[6] Pendzhiev, A.M., 2018. Agrotechnics of growing a 
melon tree in protected ground conditions: monograph / A.M. Pendzhiev. -Moscow: Rusays. pp. 222.

[7] Pendzhiev, A.M., Penzhieva, D.A., 2015. Resources and efficiency of geothermal water use ": monograph / - Germany: LAP LAMBERT Academic Publishing. pp. 224.

[8] Pendzhiev, A.M., 2017. Basics of GIS in the development of renewable energy: monograph / A.M. Pendzhiev - Germany: LAP LAMBERT Academic Publishing. pp. 308. 